\title{
A Two Years Study on Vectors of Cutaneous Leishmaniasis. Evidence for Sylvatic Transmission Cycle in the State of Campeche, Mexico
}

\author{
Eduardo A Rebollar-Téllez ${ }^{+}$, Alejandro Ramírez-Fraire, \\ Fernando J Andrade-Narvaez
}

\author{
Departamento de Inmunologia, CIR “Dr. Hideyo Noguchi”, Universidad Autónoma de Yucatán, \\ Apdo. Postal 2-1277, Mérida, Yucatán 97240, Mexico
}

Vectors of cutaneous leishmaniasis in the State of Campeche were studied in relation to the transmission cycle of Leishmania (Le.) mexicana. To determine how transmission of leishmaniasis occurs, we collected phlebotomine sand flies for two years. In the first year (October 1990 to November 1991) the collections were made with CDC light traps, Shannon traps and direct captures at natural shelters around the village (<200 $\mathrm{m}$ ) of La Libertad. In the second year (February 1993 to January 1994) the catches were performed at $8 \mathrm{~km}$ southeast of La Libertad in the forest. Female sand flies were examined for Leishmania. During the first year, 347 sand flies of nine species were collected, most of which were Lutzomyia deleoni (61.3\%). When all nine species were considered, more females than males were captured. Low densities of anthropophillic species of sand flies around the village indicated that sylvatic transmission was taking place. For the second year, 1484 sand flies of 16 species were caught. The most common were L. olmeca olmeca (21.7\%), L. cruciata (19.2\%) and L. ovallesi (14.1\%). Similarly, more females were caught than males. Thirty-five females of five species were found infected with flagellates believed to be Leishmania sp. The highest infection rate was found in L. olmeca olmeca (7.1\%) followed by L. cruciata (4.5\%) and L. ovallesi (1.1\%). These data plus other evidence on the epidemiology of human cases and results from reservoir studies are discussed in relation to the sylvatic transmission cycle.

Key words: leishmaniasis - transmission cycle - vector ecology - Lutzomyia - Mexico

Cutaneous leishmaniasis was first reported in Mexico by Seidelin (1912) who named it "chiclero's ulcer". Later, it was reported as an endemic disease on the peninsula of Yucatan, constituting an occupational hazard among forest labourers (Beltran \& Bustamante 1942). Biagi (1953) identified the causative parasite as a subspecies of Leishmania tropica, but Garham (1962) identified the parasite as Le. mexicana. Recently, Grimaldi et al. (1987) confirmed that Le. (Leishmania) mexicana was the most common parasite responsible for chiclero's ulcer based on monoclonal antibody studies. However Pérez-Motul et al. (1994) demonstrated that Le. (Viannia) braziliensis is also present on the peninsula of

This investigation received financial support from UNDP/WORLD BANK/ WHO Special Programme for Research and Training in Tropical Diseases (TDR) ID 900248.

${ }^{+}$Corresponding author. Current address: Department of Biological Sciences, Keele University, Staffordshire ST5 5BG, United Kingdom. Fax: (1782) 630007

Received 20 November 1995

Accepted 20 May 1996
Yucatán, but at a very low prevalence. The distribution of cases of leishmaniasis corresponds to the distribution of forests in Quintana Roo, Campeche and the southern region of the State of Yucatan. In the State of Campeche the annual incidence rate of leishmaniasis is 5.08 per 1000 inhabitants (Andrade-Narvaez et al. 1990). The population at high risk are males between 14-45 years old who frequently travel deep into the forest for agricultural activities (Andrade-Narvaez et al. 1992).

Vectors of New World leishmaniasis are small haematophagous Diptera of the genus Lutzomyia (Young \& Arias 1991). Apart from some taxonomical or distributional reports on sand flies (e. g., Vargas \& Diaz-Nájera 1953, Biagi et al. 1966a), relatively few entomological studies have been performed on the Yucatan peninsula. However, Biagi et al. (1965) studied sand flies in the State of Quintana Roo, where they found seven females of $L$. olmeca (5.9\%) naturally infected with flagellates. They also proved that experimentallyinfected females of L. olmeca could transmit the parasite to humans during bloodfeeding.

Despite their findings, there remains little knowledge in Mexico about important aspects of the transmission cycle including vector population, 
seasonal distribution, and vector capacity of other species of sand flies as vectors.

In our two year study, the main objective was to determine whether transmission of cutaneous leishmaniasis in the State of Campeche was peridomestic or sylvatic. This included studies on anthropophillic species and natural infection rates.

\section{MATERIALS AND METHODS}

Study area -The first year study was carried out in the village of $\mathrm{La}$ Libertad $\left(18^{\circ} 34^{\prime} \mathrm{N}, 90^{\circ}\right.$ $\left.31^{\prime} \mathrm{W}\right)$, Campeche, Mexico. Population of this village is presently 922 inhabitants. From 1987 to 1995, 48 cases of cutaneous leishmaniasis have been well-documented.

The second year study was conducted $8 \mathrm{~km}$ southeast of La Libertad, elevation (150 m a.s.l.). Due to the Mayan agricultural practices, some areas within the forest are cleared and planted with crops, mainly corn. These areas are used only for a few years and then abandoned, so at present the original forest has been mostly destroyed and only a few large trees remain e.g., gum-trees (Malnikara sapota), chaka-trees (Bursera simaruba), punab-trees (Swetenia macrophylla) and ramon-trees (Brosimun alicastrum). Farmers usually go to these places to work in their cornfields. We selected a representative site which included some areas of old forest (>12 years old), areas of dense bushes and cornfields, all of which were close one to another.

The weather in the area is classified as dry-humid, the dry season occurring from May to July. December and January are the coolest and most humid months of the year (Flores \& Espejel 1994).

Sand fly collections - During the first year, sand flies were captured around the village $(<200 \mathrm{~m})$ from October 1990 to September 1991 during three nights every month. Three CDC light traps (Sudia \& Chamberlain 1962) were set from 18:00 to 21:00 $\mathrm{hr}$ and at $100 \mathrm{~m}$ interval and a triangular arrangement. A Shannon trap (Shannon 1939), 1.6 x $2.5 \mathrm{x}$ $1.6 \mathrm{~m}$, was placed at $30 \mathrm{~cm}$ above the ground. Inside the Shannon trap, two persons attracted the flies, but they were protected from bites by their long-sleeves shirts, long slacks, and a fine mosquito screen-net covering the head (Perez et al. 1987). All sand flies landing on either the collectors or walls of the trap were collected. Collections were made every $30 \mathrm{~min}$ from 17:00 to 7:00 $\mathrm{hr}$. During the day, two persons searched in the holes of dead logs for resting sand flies, the flies were collected using a mouth aspirator. All sand flies caught from all three sampling methods, were preserved dry between layers of tissue paper in a small pillbox.
During the second year, from February 1993 to January 1994 catches were performed in the forest, monthly during four nights. Three CDC light traps were set at $1 \mathrm{~m}$ height above ground level at intervals of about $50 \mathrm{~m}$ and from 17:00 to 23:00 $\mathrm{hr}$. The Shannon trap was used in the same way as the previous year, except that it was operated from 17:00 to 23:00 hr. All flies caught from either CDC light traps or Shannon trap were placed in small vials containing saline solution $(0.65 \%)$, gentamicine sulphate $(1 \mathrm{mg} / \mathrm{ml})$ and glycerol $(10 \%)$. Later at the laboratory of Immunology of the Regional Research Centre "Dr. Hideyo Noguchi" of the University of Yucatan, the flies were dissected, and their the guts were checked for leishmanial infection.

Identification of sand flies and parasite - The flies collected in the first year study were processed for slide mounting following the technique of Young and Perkins (1984). The keys of Forattini (1973), Young (1979), Murillo and Zeledon (1985) were followed to identify the sand flies. Dissected female sand flies from the second year, were identified using the shape of the spermatheca and number of cibarial teeth. Positive slides of infected sand flies were stained with Giemsa and parasites were examined under light-microscope using 40 and $100 \mathrm{X}$ objectives. No attempts to isolate the parasite were made.

\section{RESULTS}

During the first year, 347 sand flies of nine species were collected, the majority being $L$. deleoni $(61.3 \%)$ and L. cruciata $(13.7 \%)$ (Table I). More females were captured than males ( $t$ test= 14.14; $\mathrm{df}=8, \mathrm{P}<0.01)$. However, when sample size of the known anthropophillic species, such as $L$. cruciata, L. ovallesi, L. panamensis, L. shannoni and the proven vector $L$. o. olmeca, the number of females was only 83 , constituting $23.2 \%$ of the catches. Only 50 females $(14.0 \%)$ of $L$. cruciata (40), L. o. olmeca (5) and L. panamensis (5) were collected in the Shannon trap. Anthropophillic species were caught mainly between the months of December and March. The nightly peak of catches was between 19:00 to 20:00 hr. The highest number of sand flies was obtained with CDC traps $(46.5 \%)$ followed by direct searching in natural shelters (37.0\%) and in the Shannon trap (16.5\%). These results indicated that near La Libertad, densities of anthropophillic species of sand flies were very low.

During the second year, 1484 sand flies of 16 species were caught. The most abundant species were L. o. olmeca $(21.7 \%)$, L. cruciata $(19.2 \%)$ and $L$. ovallesi $(14.1 \%)$ (Table II). More females were captured than males ( $\mathrm{t}$ test $=55.4 ; \mathrm{df}=15$, 
TABLE I

Total number of sand flies species collected in the first year (October 1990- September 1991) at La Libertad, Campeche, Mexico

\begin{tabular}{|c|c|c|c|c|c|c|}
\hline \multirow[b]{2}{*}{ Species } & \multicolumn{5}{|c|}{ Sampling method } & \multirow{2}{*}{$\begin{array}{c}\text { Relative } \\
\text { abundance \% }\end{array}$} \\
\hline & NS & $\mathrm{CDC}$ & ST & $\mathrm{F}$ & Total & \\
\hline L. carpenteri & -- & 26 & 1 & 27 & 41 & 11.5 \\
\hline L. cayennensis & 5 & -- & -- & 5 & 11 & 3.1 \\
\hline L. cruciata $^{a}$ & 4 & 4 & 39 & 47 & 49 & 13.7 \\
\hline L. deleoni & 14 & 96 & 5 & 115 & 219 & 61.3 \\
\hline L. gomezi & -- & 2 & -- & 2 & 3 & 0.8 \\
\hline L. o. olmeca ${ }^{b}$ & -- & 1 & 5 & 6 & 6 & 1.7 \\
\hline L. ovallesi ${ }^{a}$ & -- & -- & -- & -- & 2 & 0.6 \\
\hline L. panamensis ${ }^{a}$ & -- & 3 & 3 & 6 & 15 & 4.2 \\
\hline L. shannoni ${ }^{a}$ & 3 & 1 & -- & 4 & 11 & 3.1 \\
\hline
\end{tabular}

$\mathrm{NS}=$ natural shelters, $\mathrm{CDC}=$ light trap, $\mathrm{ST}=$ Shannon trap, $\mathrm{F}=$ female, $a$ : anthropophilic. $b:$ proven vector, $L:$ Lutzomyia

TABLE II

Total number of sand flies collected and examined for flagellates. Flies were captured with CDC light-traps and Shannon trap in the second year (February 1993January 1994) in a forest $8 \mathrm{~km}$ southeast of Libertad, Campeche, Mexico

\begin{tabular}{|c|c|c|c|}
\hline Species & No. collected & No. dissected & No. $+(\%)$ \\
\hline L. aclydifera & 10 & 7 & --- $(0.0)$ \\
\hline L. cayennensis & 30 & 30 & $---(0.0)$ \\
\hline L. carpenteri & 116 & 116 & $---(0.0)$ \\
\hline L. cratifera & 20 & 20 & $---(0.0)$ \\
\hline L. cruciata $^{a}$ & 269 & 269 & $12(4.5)$ \\
\hline L. deleoni & 91 & 91 & $---(0.0)$ \\
\hline L. dodgei & 3 & 1 & $---(0.0)$ \\
\hline L. gomezi & 65 & 65 & $---(0.0)$ \\
\hline L. o. olmeca ${ }^{b}$ & 282 & 282 & $20(7.1)$ \\
\hline L. ovallesi ${ }^{a}$ & 186 & 186 & $2(1.1)$ \\
\hline L. panamensis ${ }^{a}$ & 69 & 69 & $--(0.0)$ \\
\hline L. permira & 33 & 33 & $1(3.0)$ \\
\hline L. serrana & 18 & 15 & $---(0.0)$ \\
\hline L. shannoni ${ }^{a}$ & 82 & 82 & $1(1.2)$ \\
\hline L. trinidadensis & 11 & 9 & $--(0.0)$ \\
\hline L. undulata & 17 & 13 & $--(0.0)$ \\
\hline Total & 1299 & 1288 & $36(16.9)$ \\
\hline
\end{tabular}

$a$ : anthropophilic species, $b$ : proven vector, + No. females with flagellates; L: Lutzomyia; Results of this Table were taken from Navarro-Correa (1995).

$\mathrm{P}<0.01)$. The three former species, plus $L$. panamensis and L. shannoni, (the anthropophillic subset), represented $68.9 \%$ of all sand flies collected. Of these five anthropophillic sand flies, 35 females (Table II) were found infected with Leishmania sp. Although anthropophillic species were collected throughout the year, infected females of the five species were found only between November 1993 and February 1994. Twenty five of these flies had promastigote flagellates in their midguts. One female of $L$. ovallesi was found with both promastigote and amastigote forms of Leishmania sp., indicating that it had had a very recent bloodmeal.

The seasonal abundance for these five anthropophillic species was similar, except that $L$. o. olmeca had the highest peak in October. The maximum catches of flies in the Shannon trap was between 18:00 to 19:00 $\mathrm{hr}$.

\section{DISCUSSION}

The low numbers of sand flies captured at $\mathrm{La}$ Libertad could be due to deforestation. Only small bushes remain around the village, therefore favourable conditions for sand fly breeding sites, such as shaded areas and soil with high content of organic matter, is limited. The most common species collected around the village was $L$. deleoni, a non-anthropophillic species (Forattini 1973), and its presence could be used as an indication that the risk of leishmaniasis transmission is low. This sand fly species might be more associated with opossums or armadillos living nearby the village (Rebollar-Tellez unpublished data). Moreover, $L$. deleoni has never been incriminated as vector of leishmanaisis.

Results from the second year were consistent with the results of Biagi et al. (1966b). Who found a peak of biting activity between 18:00 to 19:00 hr for the anthropophillic species of sand flies in the county of Escárcega, Campeche, Mexico. On the other hand, Biagi et al. (1965) incriminated $L$. olmeca as a proven vector of cutaneous leishmaniasis in Quintana Roo. In this two-year study, females of L. o. olmeca had the highest infection rate $(7.1 \%)$ of all the species of sand flies collected in the forest. Females of L. o. olmeca and other members of the L. flaviscutellata complex, are mainly zoophillic, feeding on ground-dwelling rodents (Shaw \& Lainson 1968), but sometimes 
biting humans who enter the forest. Our results support Biagi et al. (1965) who showed that $L$. $O$. olmeca is relatively anthropophillic. The same species has been reported as a vector of Le. mexicana transmission in Belize at an infection rate of $0.5 \%$ (Disney 1968).

The second highest species infected was $L$. cruciata which has been suspected to be a vector due to its highly anthropophillic habit (Biagi et al. 1966b). Also, Disney (1968) found a 0.5\% infection rate of females collected in Belize. Transmission of parasite to human from experimentally-infected females has been proved (Williams 1970). In Guatemala, a $0.20 \%$ infection rate was reported by Rowton et al. (1991). In Quintana Roo, Mexico, L. cruciata was by far the most anthropophillic species of sand flies collected on human bait (CruzRuiz et al. 1994). Whilst, in a subsequent study of the present work, Rebollar-Téllez et al. (1996a) reported L. cruciata in Campeche as the only species collected on human bait catches re-confirming the highly anthropophillic behaviour of this species. Additionally, Rebollar-Téllez et al. (1996b) reported a survival rate of 0.68 per gonotrophic cycle for $L$. cruciata population in Campeche, indicating that L. cruciata females could survive long enough to acquire the parasite during the first blood-meal and subsequent transmission in the following cycle.

These two species, L. o. olmeca and L. cruciata, can be associated with transmission of cutaneous leishmaniasis caused by Le. (Le.) mexicana in the Peninsula of Yucatan. Data recorded in the program "Study, Surveillance and Control of Leishmaniasis, Mexico" (1987-1995) indicated that the number of human cases at La Libertad reached a peak from January to April constituting approximately $70 \%$ of all cases reported each year. Men aged 14 or more years, were most commonly infected (A.-Vargas-González, University of Yucatán, per. com.). Also, most patients believed that they had been bitten by sand flies and presumably infected with Leishmania in fields located far from the village. The main transmission period of new cases of leishmaniasis is correlated with high population densities of $L$. o. olmeca in October. The number of infected females of both $L$. $O$. olmeca and L. cruciata was found mainly during the months of November, December and January. Rebollar-Téllez et al. (1996a) reported that population of L. cruciata in Campeche, Mexico, had peak from December to March. Furthermore, in the same study area, and since November 1993, small rodents of the species Oryzomys melanotis, Ototylomys phyllotis and Sigmodon hispidus were found infected with Le. (Le.) mexicana. These strains were identical to those isolates from humans
(Chablé-Santos et al. 1995). These data suggest that densities of $L$. o. olmeca and $L$. cruciata with a high infected rate, appearance of infected reservoirs, and human activities in the forest at this time, seem to result in seasonal transmission from $\mathrm{No}-$ vember to March each year.

On the other hand, the two infected flies of $L$. ovallesi might be associated with transmission of cutaneous leishmaniasis caused by $L e .(V$. braziliensis. L. ovallesi has been found naturally infected with Le. (V.) braziliensis in Guatemala (Rowton et al. 1992). In Venezuela, unidentified flagellates were also detected in $L$. ovallesi females $(0.08 \%)$ (Feliciangeli et al. 1988). In the same country, 21 females $(0.5 \%)$ of $L$. ovallesi were infected with flagellates in their midgut and hindgut, indicating Le. (V.) braziliensis (Bonfante-Garrido et al. 1991). In our study, we found flagellates in the midgut of $L$. ovallesi, but, we were not able to establish if parasites were also present in the hindgut, which would have suggested they were $L e$. (V.) braziliensis.

In the Yucatan Peninsula seven isolates from human cases of leishmaniasis caused by $L e$. $(V$.) braziliensis have been identified by isoenzymes and by indirect immunoflourescence with monoclonal antibodies (MAbs) (Canto-Lara et al. 1996). Three isolates of Le. $(V$.$) braziliensis were con-$ firmed by kDNA hybridization technique (PérezMotul et al. 1994). Since L. ovallesis seems to be the natural vector of $L e .(V$.$) braziliensis, the uni-$ dentified flagellates found in $L$. ovallesi may have been conspecific with Le. $(V$.) braziliensis. However, the isolation and correct identification and characterization of Le. (V.) braziliensis from wildcaught females of $L$. ovallesi are needed to confirm our suggestion.

Regarding the role played by L. permira, it is not possible to evaluate its vector potential, since it was collected at a very low density ( 33 females/ year).

In summary, the evidence supports the hypothesis of sylvatic transmission in the State of Campeche, but more studies are needed to fully confirm our conclusions.

\section{ACKNOWLEDGEMENTS}

To many people at La Libertad, Campeche, for their help and facilities in conducting this research. To the Parasitology team of the Department of Immunology. The senior writer acknowledges the help of Alberto Vargas-González, Nelly E Albertos-Alpuche and N Van Wynsberghe, University of Yucatan for reading an early draft of this paper.

\section{REFERENCES}

Andrade-Narvaez FJ, Simmonds-Diaz E, Rico-Aguilar S, Andrade-Narvaez M, Palomo-Cetina M, Canto- 
Lara S, García Miss MR, Madera-Sevilla M, Albertos-Alpuche NE 1990. Incidence of localized cutaneous leishmaniasis (chiclero's ulcer) in Mexico. Trans Soc Trop Med Hyg 84: 219-220.

Andrade-Narvaez FJ, Albertos-Alpuche NE, Canto-Lara SB, Vargas-Gonzalez A, Valencia-Pacheco G, Palomo-Cetina A, Ramirez-Fraire A, Loria-Lara J, Ceron-Espinosa J, Madera-Sevilla M, EscalanteCervantes M, Esquivel-Viñas R, Cardenas-Marrufo MF, Damian-Centeno AG 1992. Risk factors associated with cutaneous leishmaniasis infection and disease in the state of Campeche, Peninsula of Yucatan, Mexico, p. 193-205. In P Wijeyaratne, T Goodman, C Espinal (eds). Leishmaniasis Control Strategies: A Critical Evaluation of IDRC-Supported Research.

Beltran E, Bustamante ME 1942. Datos epidemiologicos acerca de la "úlcera de los chicleros" (Leishmaniasis Americana) en Mexico. Rev Inst Salub Enf Trop 3: 1-28.

Biagi F 1953. Algunos comentarios sobre leishmaniasis y sus agentes etiológicos, Leishmania tropica mexicana, nueva sub-especies. Medicina (Mex) 33: 385-396.

Biagi AM de, Beltrán F, Biagi F 1966a. Nuevos conocimientos sobre los flebótomos del area endémica de leishmaniasis cutánea en Yucatán. Rev Invest Salud Publ 26: 139-153.

Biagi F, Biagi AM de, Beltran F 1965. Phlebotomus flaviscutellatus, transmisor natural de Leishmania mexicana. Prensa Med Mex 30: 267-272.

Biagi F, Biagi AM de, Beltran F 1966b. Actividad horaria de Phlebotomus antropofílicos en la Península de Yucatan. Rev Inst Salud Publ 26: 7377.

Bonfante-Garrido R, Urdaneta R, Urdaneta I, Alvarado J 1991. Natural infection of Lutzomyia ovallesi (Diptera: Psychodidae) with Leishmania in Duaca, Lara State, Venezuela. Trans $R$ Soc Trop Med Hyg 85: 61

Canto-Lara SB, Cardenas-Marrufo MF, VargasGonzález A, Andrade-Narvaez FJ 1996. Isoenzyme characterization of Leishmania isolated from human cases with localized cutaneous leishmaniasis from the state of Campeche, Mexico. Am J Trop Med Hyg (submitted).

Chablé-Santos JB, Van Wynsberghe N, Canto-Lara SB, Andrade-Narvaez FJ 1995. Isolation of Leishmania (L.) mexicana from wild rodents and their possible role in the transmission of localized cutaneous leishmaniasis in the state of Campeche, Mexico. Am J Trop Med Hyg 53: 141-145.

Cruz-Ruiz AL, Garcia-Rejon J, Manrique-Saide P, PerezMotul J 1994. Taxonomical identification of anthropophilic species of Lutzomyia in Quintana Roo, Peninsula of Yucatan, Mexico. Rev Biomed 5: $127-131$.

Disney RH 1968. Observations on a zoonosis: Leishmaniasis in British Honduras. J Appl Ecol 5: 1-59.

Feliciangeli MD, Reyes RM, Limongi JE 1988. Natural infection of Lutzomyia ovallesi (Diptera:
Psychodidae) with parasites of the Leishmania braziliensis complex in a restricted focus of cutaneous leishmaniasis in northern Venezuela. Mem Inst Oswaldo Cruz 83: 393-394.

Flores JS, Espejel I 1994. Tipos de vegetación en la Peninsula de Yucatan. Etnoflora Yucatanense. Fascículo 3, 135 pp.

Forattini OP 1973. Entomologia Medica IV. Psychodidae. Phlebotominae. Leishmanioses. Bartonelose. Edgar Bulcher, São Paulo, 658 pp.

Garham PCC 1962. Cutaneous leishmaniasis in the New World with special reference to Leishmania mexicana. Scientific Reports of Instituto Superiore di Sanita 2: 76-82.

Grimaldi G, David JR, McMahon-Pratt D 1987. Identification and distribution of New World Leishmania species characterized by serodeme analysis using monoclonal antibodies. Am J Trop Med Hyg 36: 270287.

Murillo CM, Zeledon R 1985. Flebótomos de Costa Rica. Brenesia No. 23. 137 pp.

Navarro-Correa N 1995. Especies de Lutzomyia spp. como vectores potenciales de leishmaniasis cutánea localizada en una región selvática del estado de Campeche, México. Thesis Biologist, School of Medical Veterinary, University of Yucatan (unpublished)

Pérez-Motul J, Balam-Tzeek L, Canto-Lara S 1994. Identification de protozoarios del género Leishmania con sondas biotinadas de kDNA en la Península de Yucatán, Mexico. Rev Biomed 5: 60-69.

Pérez JE, Villaseca P, Llanos-Cuentas A, Campos M, Guerra H 1987. Técnicas para colectar "titiras" (Lutzomyia spp., Diptera: Psychodidae) en ambientes altoandinos peruanos. Rev Peru Ent 30: 77-80.

Rebollar-Téllez EA, Reyes-Villanueva F, FernándezSalas I, Andrade-Narváez FJ 1996a. Population dynamics and biting rhythm of the anthropophilic sand fly Lutzomyia cruciata (Diptera: Psychodidae) in Southeast Mexico. Rev Inst Med Trop São Paulo (In press).

Rebollar-Téllez, EA, Reyes-Villanueva F, FernándezSalas I, Andrade-Narváez FJ 1996b. Abundance and parity rate of Lutzomyia cruciata (Diptera: Psychodidae) in an endemic focus of localized cutaneous leishmaniasis in Southern Mexico. J Med Entomol (In press).

Rowton E, de Mata M, Rizzo N, Navin T, Porter C 1991. Vectors of Leishmania braziliensis in the Peten, Guatemala. Parassitologia 33 (Suppl. 1) 501-504.

Rowton E, de Mata M, Rizzo N, Porter CH, Navin TR 1992. Isolation of Leishmania braziliensis from Lutzomyia ovallesi (Diptera: Psychodidae) in Guatemala. Am J Trop Med Hyg 46: 465-468.

Seidelin H 1912. Leishmaniasis and babesiasis in Yucatan. Ann Trop Med Parasitol 6: 295-299.

Shannon R 1939. Methods for collecting and feeding mosquitoes in jungle yellow fever studies. Am J Trop Med 19: 131-140.

Shaw JJ, Lainson R 1968. Leishmaniasis in Brazil: II. Observations on enzootic rodent leishmaniasis in the lower amazon region. The feeding habits of the vec- 
tor, Lutzomyia flaviscutellata in reference to man, rodents and other animals. Trans $R$ Soc Trop Med Hyg 62: 396-405.

Sudia W, Chamberlain M 1962. Battery operated light trap: An improved model. Mosq News 22: 126-129.

Vargas L, Diaz-Najera A 1953. Lista de flebótomos mexicanos y su distribución geográfica (Diptera: Psychodidae). Rev Inst Salubr Enfer Trop 13: 309314.

Williams P 1970. Phlebotomine sand flies and leishmaniasis in British Honduras (Belize).Trans $R$
Soc Trop Med Hyg 64: 317-368.

Young DG 1979. A review of the bloodsucking psychodid flies of Colombia (Diptera: Phlebotominae and Sycoracinae). Inst Food Agric Sci Tech. Bull 806, University of Florida, Gainesville, 266 pp.

Young DG, Arias JR 1992. Phlebotomine sandflies in the Americas. Pan American Health Organization/ WHO, technical paper No. 33, 28 pp.

Young DG, Perkins PV 1984. Phlebotomine sand flies of North America (Diptera: Psychodidae). Mosq News 44: 263-304. 